\title{
A mulher mapuche e seu compromisso com a luta de seu povo' (2003)
}

Organização Mapuche Meli Wixan Mapu²

Desde nossa origem, desde nossa cosmovisão, nós, as mulheres Mapuche, descendemos de velhos pais e mães, nossos ancestrais, que habitam no Wenu Mapu. Fomos criadas como opostas e complementares aos nossos companheiros (wentru). Diferentes, mas com a necessidade de nos unirmos e trabalharmos juntos para criar e conservar a vida.

Historicamente o papel da mulher Mapuche tem sido fundamental em nossa sociedade. Criadora da vida, o papel da mulher é fundamental na transmissão e conservação de nosso povo, saber e cultura, levando a sabedoria dos ancestrais, dos que morreram. A mulher Mapuche é mãe, filha, irmã. Mulheres esforçadas, valentes, de grandes espíritos. A partir de nosso ventre nascem os e as guerreiras que, com

1 Este comunicado foi escrito em Santiago do Chile, em 08 de março de 2003, Dia Internacional da Mulher. Disponível em espanhol em: MIÑOSO, Yuderkys Espinosa; CORREAL, Diana Gómez; MUÑOZ, Karina Ochoa (ed.). Tejiendo de otro modo: Feminismo, epistemología y apuestas descoloniales en Abya Yala. Popayán: Editorial Universidad del Cauca, 2014, p. 403-404. Tradução de Naiara Andreoli Bittencourt (Mestranda em Direitos Humanos e Democracia pelo Programa de Pós-graduação em Direito da Universidade Federal do Paraná, integrante do NEFIL (Núcleo de Estudos Filosóficos) do PPGD-UFPR; Bolsista pela CAPES, CNPq).

2 La Meli Wixan Mapu é uma organização mapuche de Santiago do Chile que surgiu no início da década de 1990, "tentando construir política e cultura mapuche a partir da urbanidade, no calor das mobilizações de nosso povo e no marco de um processo geral de resgate e defesa e nossa identidade e territorialidade". Disponível em: http:// meli.mapuches.org/ spip.php?article8 . Declaram-se autônomos. 
sua força, defenderão nossa nação e levarão adiante a luta pela recuperação do território ancestral e a libertação de nosso povo.

Como povo vivemos a discriminação de uma sociedade racista, arrogante; como oprimidos Mapuche vivemos a exploração do sistema capitalista que nos impõe o extermínio; mas, como mulheres, suportamos uma terceira opressão, esta que afirma que somos "frágeis", que pretende nos relegar a um lugar secundário, menor na vida cotidiana, na participação, no lar ou na história. Assim, nossa dignidade tem sido permanentemente pisoteada.

Mas a mulher Mapuche soube sobreviver às opressões, às humiIhações, às discriminações e ao racismo. Primeiro à violência bárbara do espanhol e do exército chileno e hoje à servidão que nos impõe o capitalismo e o Estado, os quais, integrando-nos como mão de obra doméstica e barata nos tornam invisíveis.

$E$, é por isso, porque a opressão não terminou, que no ocorrido nos últimos cinco anos de conflito, nós, as mulheres Mapuche, temos cumprido um papel transcendental. Levamos adiante, junto a nossos Konas, o combate contra as transnacionais florestais e hidroelétricas. Caminhando em direção à recuperação de nossa "madre tierra" (ñuke mapu), formando parte, assim como nossos homens, crianças e jovens, desta luta do povo, e é por isso que hoje também somos perseguidas pelos organismos repressivos do Estado Chileno.

Na reivindicação dos direitos legítimos da mulher e do povo Mapuche:

Liberdade a nossas Prisioneiras Políticas Mapuche!

Prisão de Temuko: Angélica Ñancupil, Bernardita Chacano Calfunao, Mireya Figueroa

Prisão de Victoria: Patricia Troncoso

Prisão de Los Angeles: Carmen Paine

(As duas primeiras se encontram atualmente em seu décimo dia de greve de fome, reivindicando situações carcerárias dignas e o reconhecimento de suas condições de presas políticas)

Pela libertação da Mulher Mapuche! Pela libertação da Nação Mapuche! Weuwain! 